\title{
Antimicrobial activities of pomegranate rind extracts: enhancement by addition of metal salts and vitamin $\mathbf{C}$ Erin M McCarrell ${ }^{\dagger}$, Simon WJ Gould ${ }^{\dagger}$, Mark D Fielder, Alison F Kelly, Waffa El Sankary and Declan P Naughton*
}

Address: School of Life Sciences, Kingston University, Kingston-upon-Thames, UK

Email: Erin M McCarrell - erinmccarrell@hotmail.com; Simon WJ Gould - S.Gould@kingston.ac.uk; Mark D Fielder - M.Fielder@kingston.ac.uk; Alison F Kelly - A.Kelly@kingston.ac.uk; Waffa El Sankary - wafaa2965@hotmail.com; Declan P Naughton* - D.Naughton@kingston.ac.uk

* Corresponding author †Equal contributors

Published: 15 December 2008

BMC Complementary and Alternative Medicine 2008, 8:64 doi:10.1 186/1472-6882-8-64
Received: 22 July 2008

Accepted: 15 December 2008

This article is available from: http://www.biomedcentral.com/I472-6882/8/64

(c) 2008 McCarrell et al; licensee BioMed Central Ltd.

This is an Open Access article distributed under the terms of the Creative Commons Attribution License (http://creativecommons.org/licenses/by/2.0), which permits unrestricted use, distribution, and reproduction in any medium, provided the original work is properly cited.

\begin{abstract}
Background: Punica granatum L. or pomegranates, have been reported to have antimicrobial activity against a range of Gram positive and negative bacteria. Pomegranate formulations containing ferrous salts have enhanced although short-term, antibacteriophage activities which are rapidly diminished owing to instability of the ferrous combination. The aim of this study was to determine the antimicrobial activities of combinations of pomegranate rind extracts (PRE) with a range of metals salts with the added stabiliser vitamin C.

Methods: PRE solutions, prepared by blending rind sections with distilled water prior to sterilisation by autoclaving or filtration, were screened with a disc diffusion assay using penicillin $G$ as a control. Suspension assays were used to determine the antimicrobial activities of PRE alone and in combination with salts of the following metals; Fe (II), $\mathrm{Cu}$ (II), Mn (II) or Zn (II), and vitamin $\mathrm{C}$, against a panel of microbes following exposure for 30 mins. The test organisms included Staphylococcus aureus, Bacillus subtilis, Escherichia coli, Pseudomonas aeruginosa and Proteus mirabilis.
\end{abstract}

Results: The screening assay demonstrated that PRE exhibited activity against the Gram positive organisms at $24 \mathrm{~h}$ with no observable effect on any of the Gram negative bacteria. However, after $12 \mathrm{~h}$, zones of inhibition were only observed for Ps. aeruginosa. In contrast, using the suspension assay, addition of $\mathrm{Cu}$ (II) salts to PRE solutions extended the activities resulting in no detectable growth being observed for the PRE/Cu (II) combination against $E$. coli, Ps. aeruginosa and P. mirabilis. Minimal antimicrobial activity was observed following incubation with Fe (II), Mn (II) or Zn (II) salts alone or in combination with PRE against any of the organisms in the test panel. The addition of vitamin C markedly enhanced the activities of both PRE/Fe (II) and PRE/Cu (II) combinations against S. aureus.

Conclusion: This is the first report demonstrating the enhanced efficacy of PRE/metal salt combinations in the presence of the stabilising agent vitamin $\mathrm{C}$, to which all isolates were sensitive with the exception of $B$. subtilis. This study has validated the exploration of PRE along with additives such as metal salts and vitamin $C$ as novel antimicrobial combinations. 


\section{Background}

Antimicrobial drug resistance in human bacterial pathogens is a continuing worldwide issue and as a consequence, effective treatment and control of such organisms remains an important challenge. Bacterial resistance has appeared for every major class of antibiotic [1]. Since their introduction the emergence of resistance to antibiotics has become increasingly evident, particularly for important pathogens such as Escherichia coli (E. coli), Salmonella spp., Campylobacter spp., Enterococcus spp. and Staphylococcus spp. $[2,3]$.

Over the last decade research into the antimicrobial properties of traditional plant based medicines has been revisited [4-7]. Numerous plants have been screened for antimicrobial properties, for example Holetz and colleagues [5] tested 13 plants used in Brazilian traditional medicine and they demonstrated activity against bacteria such as Staphylococcus aureus (S. aureus) and E. coli. Meléndez et al., [7] tested 172 plant species used in Puerto Rico and they demonstrated that 14 of these showed activity against bacteria including $S$. aureus and E. coli.

Punica granatum L. (Punicaceae) referred to in English as pomegranates, have been highlighted in many studies as having antimicrobial activity against a range of both Gram positive and negative bacteria [4-7]. Prashanth and colleagues [8] tested a number of extracts of pomegranates against a range of bacteria (S. aureus, E. coli, Klebsiella pneumoniae, Proteus vulgaris, Bacillus subtilis (B. subtilis) and Salmonella typhi), and they found activity against all isolates. Braga and colleagues [9] observed that pomegranate extracts were able to inhibit not only the growth of $S$. aureus but also the production of enterotoxin. The methanolic extract derived from $200 \mathrm{~g}$ of dried pomegranate produced bactericidal effects at $1 \%(\mathrm{v} / \mathrm{v})$ over an extended incubation period (50 hours), demonstrating longevity of action.

Many bacteria have advanced protective mechanisms for the detoxification of heavy metal ions [10]. Despite this, numerous literature reports address the development of metal compounds as antimicrobial agents. Many lowmolecular-mass metal compounds exhibit bactericidal and/or bacteriostatic activities. In one study the susceptibilities of Staphylococcus strains to solutions of metal salts (in the range of $50 \mu \mathrm{mol}$ to $80 \mathrm{mmol}$ ) were determined and frequencies of resistance were found to be $\mathrm{CuSO}_{4}$ and $\mathrm{NiCl}_{2}, 36.2 \% ; \mathrm{ZnSO}_{4}, 13.6 \%$ and $\mathrm{CoCl}_{2}, 4.5 \%$ respectively [11]. In addition, all strains were sensitive to $\mathrm{AgNO}_{3}$ over the concentration range studied. Ionic silver salts have been particularly useful as a bactericide at minute concentrations. These apparent antimicrobial effects of metal ions coupled to a lack of significant toxicity in human cells has led to their incorporation into a wide range of healthcare products from catheters to wound dressings [12,13]. New metallo-antibiotic agents include a range of ligands that have been chelated to metal ions and to date, antimicrobial activities have been demonstrated for metal complexes of imidazoles, phenanthrolines, quinolones, aminoquinolines and benzoylhydrazones [1417]. Despite the growing need for new antimicrobial therapies, the mechanisms of action of many metal binding antibiotics are not fully understood [18].

The enhancement of the antimicrobial activities exhibited by pomegranate rind extracts by the addition of metal ions has been investigated by Stewart et al. [19]. Their aim was to develop a rapid screening method for the detection of tuberculosis. They demonstrated that short term exposure to a pomegranate rind extract (PRE)/ferrous salt combination for 3 minutes reduced bacteriophage levels with no effect upon the bacteria. This short duration of exposure, although effective for the bacteriophage assay, was necessary owing to the low stability observed for the PRE/ ferrous salt solutions.

The aim of this study was to enhance the activity of the PRE combination through modification of the formula by adding the stabilizer vitamin $\mathrm{C}$. Enhancing the stability is intended to allow an increase in the exposure period to extend the antimicrobial properties. The novel combination was assessed for antimicrobial effects against a range of Gram positive and negative bacteria to develop novel stable formulations to combat drug resistant bacterial infections.

\section{Methods}

\section{Preparation of pomegranate rind extracts}

PRE were prepared by blending 15 grams of finely sectioned pomegranate rind with $45 \mathrm{mLs}$ distilled water for $10 \mathrm{~min}$. The crude extract was filtered through muslin followed by Whatman No. 1 filter paper prior to autoclaving $\left(121^{\circ} \mathrm{C}\right.$ for $\left.15 \mathrm{mins}\right)$ or filter sterilisation using a $0.2 \mu \mathrm{m}$ filter (Millipore), before storage at $-20^{\circ} \mathrm{C}$ [19]. A sample of the PRE was freeze-dried to determine the dry weight content which was found to be $0.0437 \mathrm{~g} / \mathrm{ml}$.

\section{Screening assay}

Overnight cultures of the Gram positive strains $S$. aureus (NCTC 6571), B. subtilis (NCTC 6452) and the Gram negative strains E. coli (NCTC 12241), Ps. aeruginosa (NCTC 950) and $P$. mirabilis (NCTC 7827) were prepared on nutrient agar plates (Oxoid Ltd, UK). All bacterial isolates (purchased from the National Collection of Type Cultures, Health Protection Agency, UK) were suspended in Ringer's solution (Oxoid, UK) to a turbidity equivalent to 0.5 McFarland $\left(1.5 \times 10^{8} \mathrm{CFU} / \mathrm{ml}\right)$ and $100 \mu \mathrm{L}$ were spread onto Mueller-Hinton agar plates (Oxoid Limited, UK). The PRE $(10 \mu \mathrm{L})$ was then spotted onto sterile What- 
man no 1 filter paper discs ( $5 \mathrm{~mm}$ diameter) placed centrally on the plates which were incubated at $37^{\circ} \mathrm{C}$ for 24 $\mathrm{h}$ prior to recording zones of inhibition. Penicillin G (1 unit, Mast Diagnostics UK) was used as a control.

\section{Antimicrobial activity of PRE/metal salt combinations}

All reagents were purchased from Sigma-Aldrich (Poole, Dorset) and distilled water was used throughout. Overnight cultures on nutrient agar were prepared as previously described. An aliquot of PRE $(330 \mu \mathrm{l})$ was added to $700 \mu \mathrm{l}$ of the freshly prepared solutions $(4.8 \mathrm{mM})$ of metal salts $\left(\mathrm{FeSO}_{4}, \mathrm{CuSO}_{4}, \mathrm{MnSO}_{4}, \mathrm{ZnO}\right)$ and the final solution was protected from light [19]. The appropriate bacterial dilution was prepared in Ringer's solution and $50 \mu$ l were placed in a sterile Eppendorf micro-centrifuge tube with a $100 \mu \mathrm{l}$ aliquot of the PRE/metal salt solution. After exposure for 30 minutes at room temperature, the activity of the PRE/metal salt combination was neutralized by adding an equal volume of $2 \%(\mathrm{v} / \mathrm{v})$ Tween-80 (Sigma Chemical Co., UK) in Lambda buffer [19]. Serial dilutions were prepared in Ringer's solution and $10 \mu \mathrm{l}$ of each dilution was spotted onto nutrient agar plates and incubated for 24 hours at $37^{\circ} \mathrm{C}$. Each assay was conducted in triplicate.

\section{Antimicrobial activity of PRE/metal salt combinations plus vitamin C}

The assay was carried out as described above with the following addition: vitamin $\mathrm{C}$ was added to the metal salt $\left(\mathrm{FeSO}_{4}, \mathrm{CuSO}_{4}\right)$ solution immediately prior to mixing with the PRE. Aliquots of vitamin $\mathrm{C}$ were added to give final metal ion: vitamin $\mathrm{C}$ ratios (and vitamin $\mathrm{C}$ concentrations) of $1: 1(4.8 \mathrm{mM}), 1: 5(24 \mathrm{mM})$, and 1:20 (96 $\mathrm{mM})$. A $700 \mu \mathrm{l}$ aliquot of the solution of metal salt/vitamin $\mathrm{C}$ was then added to PRE prior to assay.

\section{Fractionation study}

PRE was fractionated using Millipore ultra-filtration devices (nominal M. Wgt. cut-off = 5,000 a.m.u.) and the resulting extracts tested by the screening method described above.

\section{Statistical analyses}

Statistical analyses of the results were carried out using SPSS (ver. 14) and the data were analysed by a one way Anova and Tukey's multiple comparison test.

\section{Results and discussion}

Preliminary screening employing the disc diffusion assay was utilised to compare the antimicrobial activity of the autoclaved and filter sterilised extracts following incubation for $12 \mathrm{~h}$ and $24 \mathrm{~h}$ against a panel of bacteria. The PRE, sterilised by either method, exhibited antimicrobial activity at each time point against the Gram positive organisms (S. aureus and B. subtilis) (Table 1). The autoclaved extract demonstrated slightly greater activity than the filter sterilised extract; however, this increase was not statistically significant $(\mathrm{P}=0.4)$. The Gram positive bacteria also demonstrated the largest zone of inhibition against 1 unit of penicillin $G$, with $S$. aureus revealing the largest zone of inhibition.

For the Gram negative organisms, a small zone of inhibition ( $7 \mathrm{~mm}$ ) was observed with Ps. aeruginosa at $12 \mathrm{~h}$ incubation with extracts from both sterilisation procedures; however, at $24 \mathrm{~h}$ no zone of inhibition could be detected with any Gram negative bacteria in the test panel (Table 1 ). This may indicate an inhibition of physiological processes that is overcome upon extended incubation. A zone of inhibition with penicillin $\mathrm{G}$ was only observed against $P$ s. aeruginosa and no inhibition was seen with either $P$. mirabilis or E. coli.

Meléndez and Capriles [7] tested the antimicrobial properties of a number of tropical plants from Puerto Rico using the disc diffusion method against E. coli and $S$. aureus. They demonstrated that pomegranate extract produced inhibition zone sizes of 11 and $20 \mathrm{~mm}$, for $E$. coli and $S$. aureus respectively. Thus, their results contrast to the present study in that a smaller zone of inhibition for $S$. aureus was observed along with antimicrobial activity against E. coli. Nascimento et al. [20] prepared ethanol extractions of a number of plants and tested these against a range of laboratory and clinical isolates. Interestingly, this group only reported antimicrobial activity for pomegranate extracts against laboratory strains of Ps. aeruginosa and B. subtilis. In their test, B. subtilis produced a zone of clearing equal to or greater than $7 \mathrm{~mm}$. These differences may in part be due to the different extraction methods employed, potentially the freshness of the fruit used, and variations in the season and region of growth.

Table I: Diameter of the zones of inhibition $(\mathrm{mm})$ of the autoclaved pomegranate rind extract compared to penicillin and the results of the fractionation PRE against a panel of five bacteria.

\begin{tabular}{lccccc}
\hline Organism & $\mathbf{1 2} \mathbf{h}$ & $\mathbf{2 4} \mathbf{h}$ & Penicillin G & Low Molecular Weight Fraction & Whole PRE fraction \\
\hline S. aureus & 14 & 14 & 36 & $11 \pm 0.25$ & $14 \pm 0.14$ \\
B. subtilis & 10 & 10 & 32 & $13 \pm 0.09$ & $15 \pm 0.14$ \\
Ps. aeruginosa & 7 & 0 & 9 & 0 & 0 \\
P. mirabilis & 0 & 0 & 0 & 0 & 0 \\
E. coli & 0 & 0 & 0 & 0 & 0
\end{tabular}


Variations in results between studies on pomegranate extracts are not only seen in disc diffusion assays, but have also been recorded with minimum inhibition concentration (MIC) determinations. Values for MIC have been reported in a number of studies, ranging from $0.62-10$ $\mathrm{mg} / \mathrm{ml}$ against $S$. aureus, E. coli and Ps. aeruginosa [4] and up to $250 \mathrm{mg} / \mathrm{l}$ against $S$. aureus [21]. These differences could be due to the extraction method, freshness of the fruit, season and region of growth.

The antimicrobial activities of whole PRE/metal salt combinations were assessed using a modified version of the method adopted by Stewart et al. [19]. The PRE alone did not exhibit antimicrobial activity against any of the isolates, which may be due to the short incubation time of 30 minutes. However, the data from the previous disc diffusion assays demonstrate that if left for a longer period of time (12 and $24 \mathrm{~h}$ ), PRE alone shows antimicrobial effects against three of the five bacteria tested, as has been shown previously. The metal salts alone showed a minimal amount of activity, with a reduction of circa $10^{1}-10^{2} \mathrm{CFU} /$ $\mathrm{ml}$ in cell population, however the greatest decrease (circa $\left.10^{4} \mathrm{CFU} / \mathrm{ml}\right)(p<0.5)$ was seen with $E$. coli upon addition of Fe (II), $\mathrm{Cu}$ (II), and $\mathrm{Zn}$ (II) ions.

For the Gram negative bacteria the combination of PRE/ $\mathrm{Cu}$ (II) resulted in no detectable growth for all three isolates after 30 mins (Fig 1), giving better results than the PRE or Cu (II) alone $(p<0.001)$. Conversely the combinations of PRE with the other metals salts were less active than the PRE and metal salts individually. A number of possible reasons exist for this observation; the PRE and other metal salts (Zn (II) and Mn (II)) may not have formed complexes. In addition, the lack of antimicrobial activity could be due to the PRE and $\mathrm{Zn}$ (II) or Mn(II) having formed a complex that owing to instability had little or no effect on the bacteria.

Moderate antimicrobial activity was seen with the PRE/Cu (II) ions in combination against $S$. aureus reducing the surviving population by circa $10^{3} \mathrm{CFU} / \mathrm{ml}$ compared to the buffer (Fig 2). The remaining solutions of metal ions or their combinations with PRE only demonstrated minor or no antimicrobial effects against $S$. aureus. The difference in the results seen between the $S$. aureus compared to

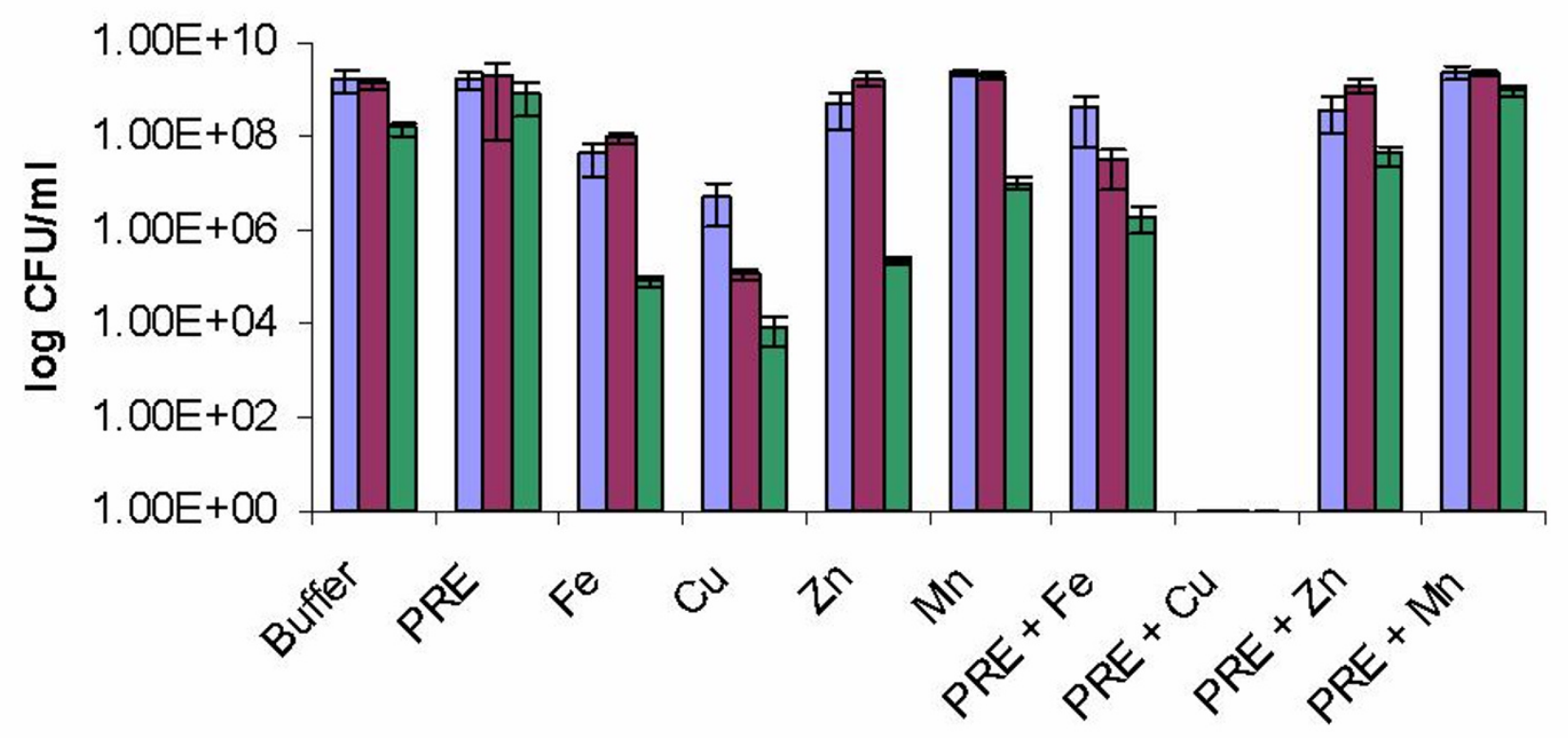

Solution

Ps. aeruginosa $\square$ P. mirabilis $\square$ E.coli

\section{Figure I}

The antimicrobial activities of PRE alone and in combination with metal ions against Ps. aeruginosa, $P$. mirabilis and E. coli. Lambda buffer was used as a control and error bars are SEM for each sample tested. 
the Gram negative bacteria for the combination of PRE/ $\mathrm{Cu}(\mathrm{II})$ is interesting. As the mode of action of this combination against bacteria is currently unknown; these results suggest that a thick cell wall, as present in the Gram positive bacteria, may inhibit the uptake/action of this potential antimicrobial combination.

Minimal differences between metal ions or combinations with PRE and controls were detected against B. subtilis, although a reduction of approximately $10^{1} \mathrm{CFU} / \mathrm{ml}$ was obtained with PRE, the largest reduction seen in all the isolates (Fig 2). The limited antimicrobial effects seen with $B$. subtilis may be due to the high selectivity for uptake of metal ions in contrast to the non-specificity of its metal ion efflux systems [22]. However, some microorganisms have specific systems to remove metals from the cell whereas in Bacillus spp. copper is removed by a P-type ATPase protein [23].

A recent study investigated the antimicrobial affects of vanillin complexes with a number of different metal salts, against a range of bacteria [24]. Antimicrobial activity in this study was determined by agar diffusion and results showed the most active complex was vanillin and metals salts against the test bacteria ( $S$. aureus, E. coli, K. pneumaniae, P. vulgaris, P. aeruginosa, Candida albicans). The current study and report by Sivasankaran and Selwin [24] demonstrate that antimicrobial properties of natural products can be enhanced by the addition of metal ions, especially cupric salts.

Further studies were conducted to prolong the activity of the PRE/metal combination by addition of the stabiliser vitamin $\mathrm{C}$. Owing to the high activity exhibited by the $\mathrm{PRE} / \mathrm{Cu}(\mathrm{II})$ combination against all Gram negative isolates, we studied the addition of vitamin $\mathrm{C}$ to the PRE/ $\mathrm{Fe}(\mathrm{II})$ combinations (Fig 3). No enhancement of activity was recorded with two isolates, namely Ps. aeruginosa or $P$. mirabilis. For E. coli, a decrease in survival of $10^{2} \mathrm{CFU} / \mathrm{ml}$ was seen with the addition of a stoichiometric equivalent of vitamin $\mathrm{C}$ (with respect to metal ion concentration). Further additions of vitamin $\mathrm{C}$ (to 5 and 20 equivalents)

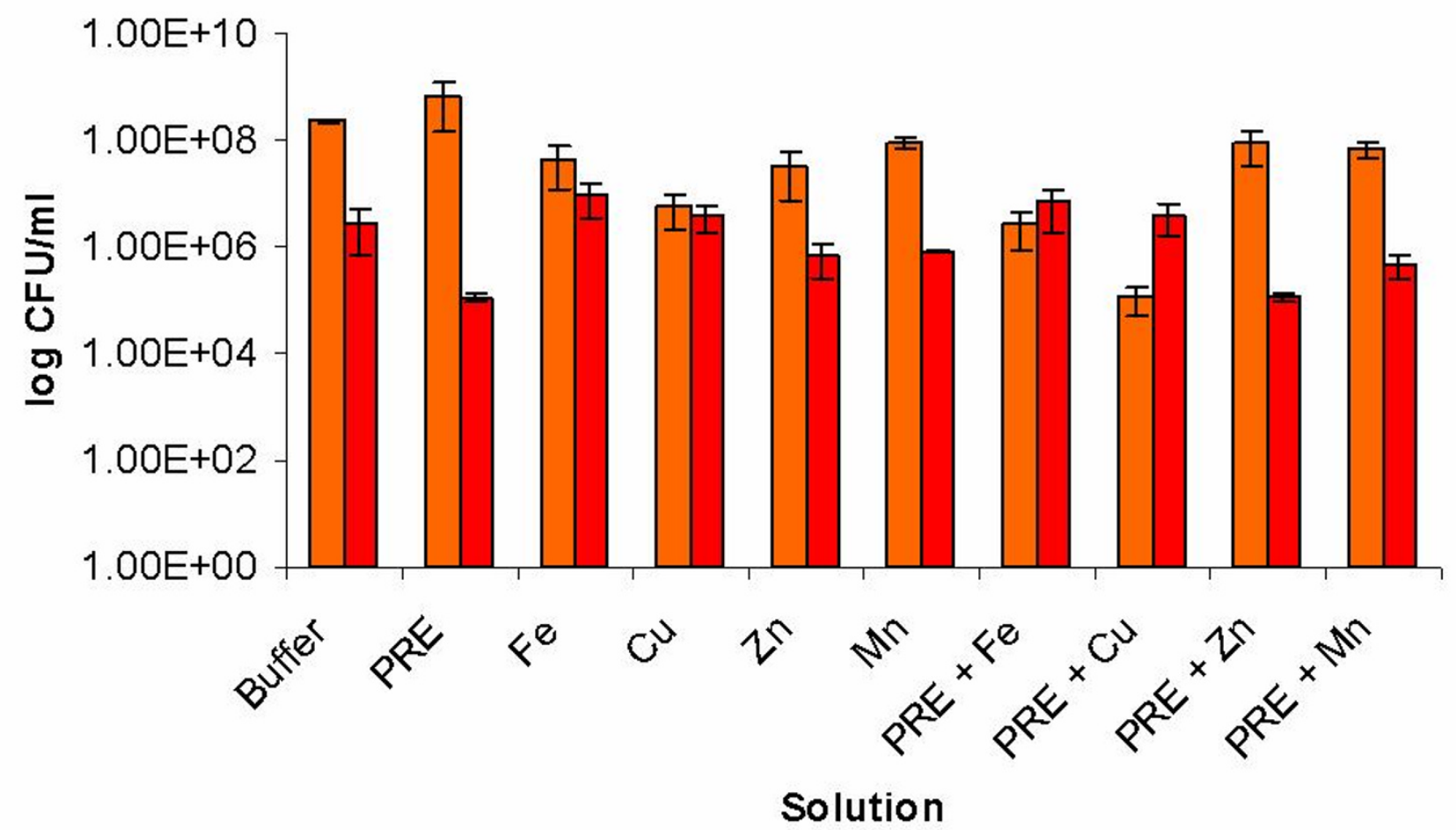

S.aureus $\square$ B.subtilis

Figure 2

The antimicrobial activities of PRE alone and in combination with metal ions against $S$. aureus and B. subtilis. Lambda buffer was used as a control and error bars are SEM for each sample tested. 


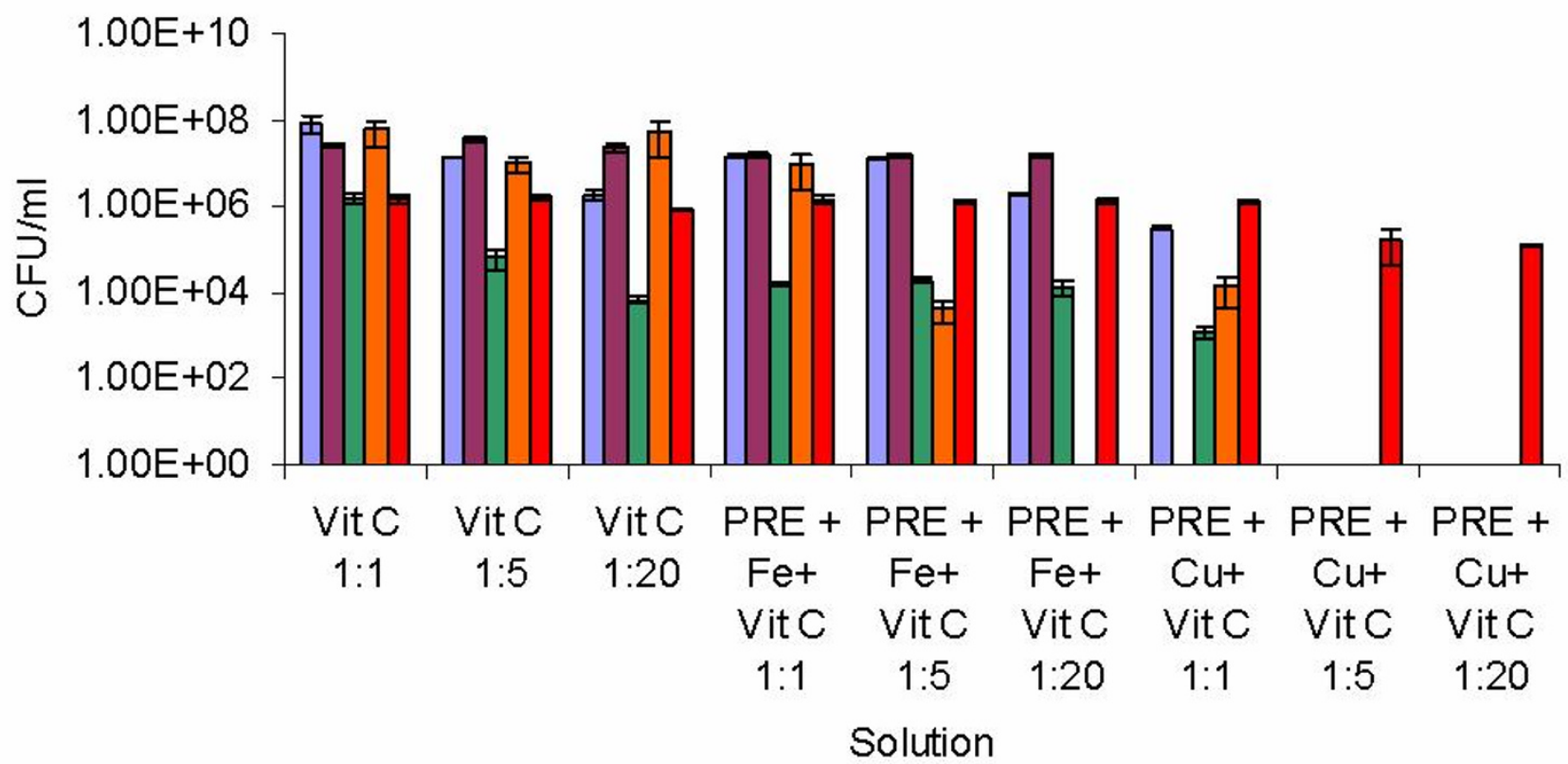

Ps. aeruginosa $\square$ P. mirabilis $\square$ E.coli $\square$ S.aureus $\square$ B.subtilis

Figure 3

The antimicrobial activities of PRE/metal ion combinations with the addition of vitamin C all isolates. Lambda buffer was used as a control and error bars are SEM for each sample tested.

had no further effects on activity. Equally, no improvement in activity was observed for the addition of one equivalent of vitamin $\mathrm{C}$ to the PRE/Fe(II) combination against $S$. aureus; however, addition of 5 and 20 equivalents of vitamin $\mathrm{C}$ resulted in a reduction in growth of $10^{3}$ $\mathrm{CFU} / \mathrm{ml}$ and no discernable growth respectively.

For $S$. aureus, the addition of vitamin $\mathrm{C}$ to the PRE/Cu(II) mixture had no significant effect at one equivalent but a marked effect at 5 and 20 equivalents of vitamin $C$ (no detectable growth in either). Addition of vitamin $\mathrm{C}$ to the PRE/Cu(II) solution had minimal effects on the survival of $B$. subtilis. Interestingly the addition of one equivalent of vitamin C decreased the efficacy of the PRE/Cu(II) with both Ps. aeruginosa and E. coli; however, further addition of vitamin $\mathrm{C}$ resulted in no recorded growth of both isolates. Further studies are required to investigate these effects.

In order to determine the approximate molecular weight fraction containing the active component(s) of crude PRE extract, it was subjected to fractionation using a molecular weight filter with a nominal 5,000 a.m.u. cut off. Similar activities were exhibited by the low molecular weight frac- tion and the intact whole PRE suggesting the antimicrobial component(s) of the PRE have low molecular weights. Analysis of the ultrafiltration device revealed that the high molecular weight fraction was negligible which in part is attributable to the PRE preparation methods.

\section{Conclusion}

Combinations of PRE with $\mathrm{Cu}(\mathrm{II})$ ions exhibit enhanced antimicrobial effects against $E$. coli, Ps. aeruginosa and $P$. mirabilis and moderate activity is observed against $S$. aureus in comparison to each component. The addition of high quantities of vitamin $\mathrm{C}$ markedly enhanced the activities of both PRE/Fe(II) and PRE/Cu(II) mixtures against $S$. aureus. Future investigations into the activity of PRE/ $\mathrm{Cu}$ (II) combinations against clinical isolates of Ps. aeruginos $a$ and $S$. aureus are being conducted. The active component(s) in the PRE was found in the low molecular weight fraction and further work is underway to isolate it and to establish the mode of action, along with the mechanism of enhancement by metal salts and vitamin C.

\section{Competing interests}

The authors declare that they have no competing interests. The study was in part funded by Nature Therapeutics Ltd. 


\section{Authors' contributions}

SWJG, MDF, AFK, WES, DPN participated in the design of the study. EMM, carried out the microbiological analysis. EMM, SWJG, MDF, AFK, DPN analysed the data and wrote the paper. All authors read and approved the final manuscript.

\section{Acknowledgements}

This work was funded in part by Nature Therapeutics Ltd and by Kingston University.

\section{References}

I. Lambert PA: Bacterial resistance to antibiotics: Modified target sites. Adv Drug Deliv Rev 2005, 57: | 47 I-I 485

2. Adesiyun A, Offiah N, Seepersadsingh N, Rodrigo S, Lashley V, Musai L: Antimicrobial resistance of Salmonella spp. and Escherichia coli isolated from table eggs. Food Cont 2007, 18:306-3II.

3. Rodrigo S, Adesiyun A, Asgarali Z, Swanston W: Antimicrobial resistance of Campylobacter spp. isolated from broilers in small poultry processing operations in Trinidad. Food Cont 2007, I 8:32I-325

4. Navarro V, Villarreal ML, Rojas G, Lozoya X: Antimicrobial evaluation of some plants used in Mexican traditional medicine for the treatment of infectious diseases. J Ethnopharmacol 1996 53:143-147.

5. Holetz FB, Pessini GL, Sanches NR, Cortez DAG, Nakamura CV, Filho BPD: Screening of Some Plants Used in the Brazilian Folk Medicine for the Treatment of Infectious Diseases. Memórias do Instituto Oswaldo Cruz 2002, 97: 1027-1031.

6. Mathabe MC, Nikolova RV, Lall N, Nyazema NZ: Antibacteria activates of medicinal plants used for the treatment of diarrhoeas in Limpopo Province, South Africa. J Ethnopharmacol 2006, 105:286-293.

7. Meléndez PA, Capriles VA: Antibacterial properties of tropical plants from Puerto Rico. Phytomed 2006, I3:272-276.

8. Prashanth D, Asha MK, Amit A: Antibacterial activity of Punica granatum. Fitoterapia 200I, 72: I7I-173.

9. Braga LC, Shupp JW, Cummings C Jett M, Takahashi JA Carmo LS, Chartone-Souza E, Nascimento AMA: Pomegranate extract inhibits Staphylococcus aureus growth and subsequent enterotoxin production. J Ethnopharmacol 2005, 96:355-339.

10. Silver S: Bacterial resistances to toxic metal ions - a review. Gene 1996, 179:9-19.

II. Ug A, Ceylan O: Occurrence of Resistance to Antibiotics, Metals, and Plasmids in Clinical Strains of Staphylococcus spp. Arch Med Res 2005, 34: I30-136.

12. O'Neill MA, Vine G], Beezer AE, Bishop AH, Hadgraft J, Labetoulle C Walker M, Bowler PG: Antimicrobial properties of silver-containing wound dressings: a microcalorimetric study. Int Pharm 2003, 263:61-68

13. Strohal R, Schelling M, Takacs M, Jurecka W, Gruber U, Offner F: Nanocrystalline silver dressings as an efficient anti-MRSA barrier: a new solution to an increasing problem. J Hosp Infect 2005, 60:226-230.

14. Anderberg PI, Harding MM, Lay PA: The effect of metal ions on the electrochemistry of the antitumor antibiotic streptonigrin. J Inorg Biochem 2004, 98:720-726.

15. Srinivasan S, Annaraj J, Athappan PR: Spectral and redox studies on mixed ligand complexes of cobalt (III) phenanthroline bipyridyl and benzoylhydrazones, their DNA binding and antimicrobial activity. J Inorg Biochem 2005, 99:876-882.

16. Efthimiadou EK, Sanakis Y, Raptopoulou CP, Karaliota A, Katsaros N Psomas G: Crystal structure, spectroscopic, and biological study of the copper(II) complex with third-generation quinolone antibiotic sparfloxacin. Bioorg Med Chem Lett 2006 , 16:3864-3867

17. Rowan R, Tallon T, Sheahan AM, Curran R, McCann M, Kavanagh K, Devereux M, McKee V: 'Silver bullets' in antimicrobial chemotherapy: Synthesis, characterisation and biological screening of some new $\mathrm{Ag}(\mathrm{I})$-containing imidazole complexes. Polyhedron 2006, 25: |77|-1778.
18. Ming 니: Structure and function of "metalloantibiotics". Med Res Rev 2003, 23:697-762.

19. Stewart GS, Jassim SA, Denyer SP, Newby P, Linley K, Dhir VK: The specific and sensitive detection of bacterial pathogens within $4 \mathrm{~h}$ using bacteriophage amplification. J Appl Micro 1998, 84:777-783.

20. Nascimento GGF, Locatelli J, Freitas PC, Silva GL: Antibacterial activity of plant extracts and pyhtochemicals on antibioticresistant bacteria. Brazilian J Microbiol 2000, 3 I:247-256.

21. Machado TB, Pinto AV, Pinto MCFR, Leal ICR, Silva MG, Amaral ACF, Kuster RM, Netto-dosSantos KR: In vitro activity of Brazilian medicinal plants, naturally occurring naphthoquinones and their analogues, against methicillin-resistant Staphylococcus aureus. Int J Antimicrob Agents 2003, 2 1:279-284.

22. Moore CM, Helmann JD: Metal ion homeostasis in Bacillus subtilis. Curr Opin Microbiol 2005, 8: 188-195.

23. Singleton C, Banci L, Ciofi-Baffoni S, Tenori L, Kihlken MA, Boetzel R, Le Brun NE: Structure and $\mathrm{Cu}(\mathrm{I})$-binding properties of the $\mathbf{N}$ terminal soluble domains of Bacillus subtilis CopA. Biochem J 2008, 4I I:57I-9.

24. Sivasankaran Nair M, Selwin Joseyphus R: Synthesis and characterization of $\mathrm{Co}$ (II), $\mathrm{Ni}$ (II), $\mathrm{Cu}$ (II) and $\mathrm{Zn}$ (II) complexes of tridentate Schiff base derived from vanillin and $D L-\alpha-$ aminobutyric acid. Spectrochim Acta 2008, 70:749-753.

\section{Pre-publication history}

The pre-publication history for this paper can be accessed here:

http://www.biomedcentral.com/1472-6882/8/64/prepub
Publish with Bio Med Central and every scientist can read your work free of charge

"BioMed Central will be the most significant development for disseminating the results of biomedical research in our lifetime. "

Sir Paul Nurse, Cancer Research UK

Your research papers will be:

- available free of charge to the entire biomedical community

- peer reviewed and published immediately upon acceptance

- cited in PubMed and archived on PubMed Central

- yours - you keep the copyright

Submit your manuscript here

http://www.biomedcentral.com/info/publishing_adv.asp
BioMedcentral 